\title{
THE CORRELATION BETWEEN STUDENTS' VOCABULARY MASTERY AND ABILITY IN ARRANGING NARRATIVE PARAGRAPHS AT SMA SWASTA SANTO PETRUS MEDAN
}

\author{
Indri Kristine br Ginting, Erikson Saragih, Jontra Jusat Pangaribuan \\ Catholic University of Saint Thomas
}

\begin{abstract}
This study attempts to investigate the correlation between students ${ }^{\text {ee }}$ vocabulary mastery and ability in arranging narrative paragraphs. The research approach was quantitative. The research method was descriptive. The research design of this study was a correlational design. The population of this study was second grade students of SMA Swasta Santo Petrus Medan totaling to 118 of three parallel classes. The sample of this research was the class XI MIA totaling to 38 students. The instrument of collecting the data were vocabulary test and arranging narrative paragraphs test and split half formula was used to obtain the reliability of the test. The data was analyzed by using Pearson Product Moment formula. From this study it was found that robserved is higher than rtable $(0.881>0.413)$. It means that null hypothesis is rejected and Alternative hypothesis is accepted. As the conclusion, there is very strong correlation between students"e vocabulary mastery and ability in arranging narrative paragraphs at SMA Swasta Santo Petrus Medan in Academic Year of 2016/2017.
\end{abstract}

Key words: vocabulary, correlation, arranging narrative paragraphs

\section{INTRODUCTION}

Vocabulary is one of the language aspects which should be learnt. Someone who has a lot of vocabulary of foreign language, he could learn language easily. Learning vocabulary is important. W e hav e to know voc abul a $\mathrm{r}$ y first in or der to be a ble to list en, sp eak, and w rite nic el y. Ac co rdin g to Hatch and Brown (1995:1), vocabulary is the foundation to build language which plays a fundamental role in communication. Neuman and Dwyer (2009:385) also stated that vocabulary can be defined as words we must know to communicate effectively. Vocabulary knowledge is often viewed as a critical tool for second language learner because a limited vocabulary in a second language impedes successful communication. It means that vocabulary is the first priority in learning English.

Realizing the importance of vocabulary mastery, many researchers have conducted researches about vocabulary mastery. They are: Setiawan (2008) stated that the implementation of direct instruction can improve the students"e vocabulary mastery. The other is Anisa (2010). Based on her research, teaching vocabulary using experimental learning can improve the students $^{\text {ee }}$ vocabulary mastery. The last, Kasim (2010) he stated that word wall media as one of the method or media in teaching is effective and significant in increasing the students ${ }^{\text {ee }}$ vocabulary mastery.

Vocabulary mastery is not only knowing the words and its meanings, but also knowing about how the words sound and how the words are used in the context. Mastering vocabulary is the ability to get or receive a lot of words. By having and mastering vocabulary, we will know the meaning of vocabulary in the context. It can also avoid in making mistakes in written or spoken text.

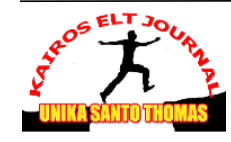


To arrange means to plan or organize something in advance. Arranging narrative paragraphs means to organize some sentences to be paragraph of narrative. In this case, the sentences that were organized have been arranged grammatically.

A narrative text is a text which is organized according to time order or chronological order. Its function to amuse, entertain and to deal with actual or vicarious experience in diffrent ways; narratives deal with problematic events which lead to a crisis or turning point of some kind, which in turn finds a resolution. The writer chose narrative because it is a very familiar kind of texts. It is always appeared in every semester since 7th grade of Junior School to 12th grade of Senior High School.

Based on the writeres observation in SMA Swasta St. Petrus Medan, students in that school have some problems in learning English because they lack of vocabulary. Ones of them is unability of students in arranging narrative paragraphs. Based on the above experience, the writer is interested to investigate the notion of the correlation between vocabulary mastery and students ${ }^{e e}$ ability in arranging narrative paragraphs.

There are some previous researches relating to the topic. The first is Anova, et.al (2004) entitled is The Correlation between Vocabulary Mastery and Speaking Skill at Fifth Semester of English Study Program in Pasir Pengairan University. It was found that there is correlation between vocabulary mastery and speaking skill at the fifth semester of English study program in university of pasir pengairan. The second is Furqon (2013) which is entitled The Correlation Between Students ${ }^{e c}$ Vocabulary Mastery and Their Reading Comprehension. In his research, it was concluded that there is a strong correlation between students ${ }^{\text {ee }}$ vocabulary mastery and their reading comprehension. Thirdly is Fauzi (2012). His research about The Correlation Betwen Students ${ }^{\text {e }}$ Vocabulary Mastery and Their Writing Narrative Ability at The First Grade Students of SMA Tut Wuri Handayani Cimahi. It is stated that there is a significant correlation between students ${ }^{e e}$ English vocabulary mastery and their writing narrative text ability.

This research is different from the researches above. The difference of this research with others is in this research the writer correlate vocabulary with arranging narrative paragraphs. It is not write a paragraph of narrative text.

It is important to do this research. We know that arranging paragraphs may found in exercises and National Exam. Because of that, teacher and students need to know what terms that influence students ${ }^{e c}$ ability in arranging paragraphs. If there is a correlation between vocabulary mastery and students ability in arranging narrative paragraphs, teacher may help the students to increase their vocabulary mastery to make them able in arranging narrative paragraphs. So, it is important to know if there is a correlation between vocabulary mastery and students ability in arranging narrative paragraphs.

\section{REVIEW OF LITERATURE Correlation}

Correlation means a connection between two things in which one thing change as the other does. According to Ary, et.al (1979:113), correlation is indicating the relationship between pairs of scores. Typically measurements on two variables are available for each member of a group and one determines if there is relationship between these paired measurements. Based on that definition it can be concluded that correlation refers to the mutual relationship between two pairs or variables.

The correlation exists if one thing mutually related to another. Correlation is also defined as influences on the other. For example if an individual gets high score in the first test, he tends to get high score in the second test. In this study, the first variable is vocabulary mastery and the second variable is students ${ }^{\text {ee }}$ ability in arranging narrative paragraphs. So there will be 
a correlation between students ${ }^{\text {ee }}$ vocabulary mastery and their ability in arranging narrative paragraphs if students who get high score in vocabulary mastery test also get high score in arranging narrative paragraph test.

\section{Vocabulary}

When we are talking about vocabulary, it means that we are talking about words. Vocabulary is one of the knowledge areas in language. It plays a great role for learners in acquiring a language. According to Nation and Newton (1997:4), vocabulary is the knowledge of words and word meaning. Burns and Broman (1975:295) also stated that vocabulary as the stock of words which is used by person, class or profession. From the definition above, it can be concluded that vocabulary is stock of words, a list or set of words in a particular language that a person knows and uses. Vocabulary skill is one of linguistic features which influence the communicative competence. Students who have acquired more vocabulary items, they will more likely to articulate and communicate the message. It means that if one doesn ${ }^{e e} t$ know any words of language, surely he will not be able to communicate thought he knows much about the rules how to construct sentences.

\section{Kinds of Vocabulary}

Hatch and Brown (1995:30) indicate two kinds of vocabulary, namely receptive vocabulary and productive vocabulary.

\section{Receptive Vocabulary}

Receptive vocabulary is words that learners recognize and understand when they are used in context, but they cannot produce. It is vocabulary that learners recognize when they see or meet in reading text but do not use it in speaking and writing. Example: when the children start reading, they will not understand all the word which they read. Its word is children receptive vocabulary.

\section{Productive Vocabulary}

Productive vocabulary is the words that the learners understand and can pronounce correctly and use constructively in speaking and writing. It involves what is needed for receptive vocabulary plus the ability to speak or write at the appropriate time. Therefore, productive vocabulary can be addressed as an active process, because the learners can produce the words to express their thoughts to others. We should remember that every person may have different receptive and productive vocabulary.

\section{Vocabulary (word) Classes}

Hatch and Brown (1995:3) stated that there are eight different word classes. They are:

a. Noun: it refers to a person, place, or thing

Examples: John, teacher, market, school, dog, book, etc.

b. Verb: it refers to the words that denote action.

Examples: walk, teach, speak, read, eat, run, etc.

c. Adjective: it refers to words that are used to highlight qualities or attributes. Certain adjectives are typically used to describe particular nouns.

Examples: light, dark, bright, and dull are used with color names.

d. Adverb: adverbs are similar to adjectives in many ways although they typically assign attributes to verbs, to clauses, or to entire sentences rather than to nouns.

Examples: carefully, diligently, honestly, etc.

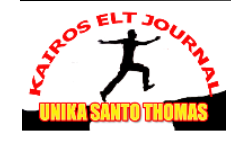


e. Pronoun: it refers to nouns that have already been mentioned in discourse or point ahead to a noun that we are about to mention.

Examples: She, he, it, they, her, etc.

f. Conjunction: it refers to words that connect sentences, phrases, or clauses

Examples: and, so, but, because, while, etc.

g. Preposition: prepositions are all those words that help locate items and actions in time and space.

Examples: at, on, beside, under, above, ahead, etc.

h. Determiner: it refers to the words that use before a noun to show which particular example of the noun you are referring to.

Examples: the, a, an, my, your, this, those, etc.

\section{Vocabulary Mastery}

Herzog $(2005: 135)$ stated that mastery as expert skill or knowledge. From that definition, it can be concluded that mastery is someone ${ }^{\text {ee }}$ ability or great skill in doing something and making a certain physical or mental response. Vocabulary mastery refers to great skill in processing words of a language. It is an individual achievement and possession. For that reason, the biggest responsibility in increasing the knowledge is individual himself. The success in widening the vocabulary mastery requires learners own motivation and interest on the words of a language. From the definition above, it can be concluded that vocabulary mastery is an individuale ${ }^{\text {ee }}$ great skill in using words of a language, which is acquired based on their own interest needs and motivation.

Vocabulary must be mastered because it is the key to the students understanding what they hear, read and communicate with other people successfully and also because it is needed to master four skills in English. Through vocabulary we can convey our ideas, emotion and efficiently. Without mastering it, people will not be able to use English effectively.

In common vocabulary mastery in Indonesian students is still poor, traditionally, students tend to learn the new words by memorizing and as a consequence they forget the words which they have learn by memorizing easily. In SMA Swasta Katolik Santo Petrus Medan, vocabulary mastery of the students also low, it can be seen in un-ability of students to communicate in English.

\section{The Assessment of Vocabulary Mastery}

To measure the studentse ability in mastering vocabulary, it should be used a test or an assessment. Measuring vocabulary usually means testing how big a learners ${ }^{\text {ee }}$ vocabulary mastery size is and how well he or she knows word. Vocabulary assessment can fulfill important roles in language education for teachers, Learners and researchers. For teacher, vocabulary assessment enables teacher to provide suitable materials for learners ${ }^{c e}$ need, to judge the efficiency of a course of a study, and to set appropriate goals for further development. For learners, vocabulary-setting is particularly important. By knowing their score after do test, they will have a desire to build their vocabulary mastery. And for research purpose, vocabulary tests could be used to better understand the relationship between lexical knowledge and other skills.

The most widely used to measure of English Vocabulary size for second language learners are Vocabulary Level Test (VLT) and Vocabulary Size Test (VST). Vocabulary Level Test requires the test-takes to match words with their synonyms or short definition (Nation and Newton, 1997:316). And Vocabulary Size Test (VST) has multiple choice format with each target word presented in a short non-defining sentence followed by four possible definitions as 
option. Both of them assess written receptive vocabulary knowledge. These two types of item provide direct evidence that each word is actually known.

In this study, the writer used Vocabulary Level Test (VLT) but in multiple choices not in matching words and also used Vocabulary Size Test (VST) to measure Students ${ }^{\text {ee }}$ vocabulary Mastery. The students as the sample were asked to do exercise in multiple choice format.

\section{Paragraph}

A paragraph is a series of sentences that develop one idea (Reid, 1987:8). Also Bram (1995:13) stated that a paragraph is a group of sentences which are contain relevant information about one main idea or central idea. From that description, it can be conclude that a paragraph is a group of related sentences which give more information about one main idea. Paragraph must be limited to a single topic. The topic is most often expressed in the topic sentence which is usually the first sentence.

Generally, a paragraph consists of an introductory or a topic sentence, a development of topic sentence or supporting idea, and a conclusion. The topic sentence states the main idea of the paragraph. It has function also as the limitation of the topic to one or two areas that can be discussed fully in a single paragraph. Supporting sentences develop the topic sentence. The supporting evidence composes the body of the paragraph. This element should consist of detailed information that is directly relevant to and further develops the main point presented in the topic sentence.

The way to develop the topic sentence can be done by giving the reason, facts, data, statistics, and quotation. It is standard to have anywhere from two to five concise supporting sentences, which is generally sufficient to develop the main point and keep the paragraph focused. And the last one is concluding sentence which is functioned to signal the end of paragraph and leaves the reader with important points to be highlighted or remembered.

\section{Arranging Narrative Paragraphs}

The word "arranging" comes from the word "to arrange". To arrange means to put something in order, make tidy neat or attractive. So, arranging narrative paragraphs means put jumbled sentences in advance to make paragraph of narrative. In relation to this study, students were asked to arrange sentences that are organize grammatically, it means that just position of the sentences that are needed to arrange not the structure of each Sentences.

Rearrange these sentences into paragraph!

1. a. Once upon a time, in the afternoon, there was a poor farmer.

b. So the farmer asked his old father to help him take the gold coins out of the

c. One sunny morning, she dropped apples in the box.

d. He lives with his wife.

e. One day, he dug his field and found a very large box.

f. Suddenly, the box gets filled with apples.

g. No matter how many apples were taken out, more apples going on inside the box.

Answer:

Once upon a time, in the afternoon, there was a poor farmer. He lived with his wife. One day, he dug his field and found a very large box. One sunny morning, he dropped apples in the box. Suddenly, the box gets filled with apples He then stored them in their homes. No matter how many apples were taken out more apples going on inside the box.

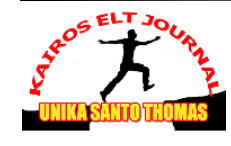


2. a. Simultaneously, apple began to disappear and the box full of gold coins.

b. He then stored them in their homes.

c. Farmer soon became rich.

d. His father was not very strong

e. After hearing that his son became wealthy, the farmers ${ }^{e e}$ father visited couples

f. His father worked hard, took the gold coins out of the box.

g. Old man said nothing and continued to work long.

h. When he was told that he was very tired and wanted to rest, the farmer yelled to him, why are you so lazy, why can "t you work harder?

i. Suddenly, man fell into the box, he died.

\section{Answer:}

Simultaneously, apple began to disappear and the box full of gold coins. Farmer soon became rich. After hearing that his son became wealthy, the farmers ${ }^{\text {ee }}$ father visited couples. His father was not very strong. So the farmer asked his old father to help him took the gold coins out of the box. His father worked hard, took the gold coins out of the box. When he was told that he was very tired and wanted to rest, the farmer yelled to him, why are you so lazy, why can "et you work harder? Old man said nothing and continued to work long. Suddenly, man fell into the box, he died.

\section{Genres}

According to Gerot and Wignell (1994:17), a genre can be defined as a culturally specific text-type which results from using language (written or spoken) to help accomplish something. There are thirteen types of academic genre; spoof, recount, reports, exposition, news item, anecdote, narrative, procedure, description, commentary, explanation, discussion and reviews.

a. Spoof

Spoof is kinds of text which has social function to retell an event with a humorous twist.

b. Recounts

It is kind of text which social function to retell events for the purpose of informing or entertaining.

c. Reports

Report is kind of text which social function to describe the way things are, with reference to a range of natural, man-made and social phenomena in our environment.

d. Analytical Exposition

It is kind of text which social function to persuade the reader or listener that something is the case

e. News Item

News item is kind of text that use to inform readers, or listeners or viewers about events of the day which are considered newsworthy or important.

f. Anecdote

It is kind of text which social function to share with others an account of an unusual or amusing incident.

g. Narrative

Narrative is a text that use to amuse, entertain and to deal with actual or vicarious experience in different ways; narratives deal with problematic events which lead to a crisis or turning point of some kind, which in turn finds a resolution.

h. Procedure

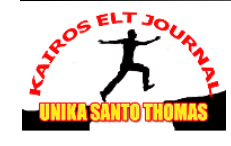


It is a text which social function to describe how something is accomplished through a sequence of action or steps.

i. Description

Description is kind of a text that social function to describe a particular person, place or thing.

j. Hortatory Exposition

It is kind of text which social function to persuade the reader or listener that something should or should not be the case.

k. Explanation

Explanation is kind of text which social function to explain the processes involved in the formation or workings of natural or social cultural phenomena.

1. Discussion

Discussion a text which social function to present (at least) two points of view about an issue.

m. Reviews

It is kind of text that use to critique an art work or event for a public audience such works of art include movies, TV shows, books, plays, operas, recordings, exhibitions, concerts and ballets.

\section{Narrative Text.}

Narratives are stories about person or a group of people overcoming problem (Joyce and Feez, 2000:24). It shows how people react to experiences, explore social and cultural values and entertain the audience. Toolan (2001:20) also stated that narrative is a perceived sequence of non-randomly connected events, typically involving, as the experiencing agonist, human or quasi-humans, or other sentient beings, from whose experience we human can learn. From the definition above, it can be concluded that narrative text is a story about person or group of people overcoming the problem which is perceived sequence of organize connected events.

\section{Social Function of Narrative Text}

Gerot and Wignell (1994:204) stated that social function of narrative is to amuse, entertain and to deal with actual vicarious experience in different ways narratives deal with problematic events which lead to a crisis or turning point of some kind, which in turn finds a resolution.

\section{Why Does the Cock Eat the Millipede? Orientation}

Long time ago the cock had a pair of beautiful horns on his head. But at that time there was a dragon which was prevented from ascending into heaven because he lacked a pair of horns. And so he offered the millipede as a guarantor, and borrowed the horns from the cock!

\section{Evaluation}

When the millipede came for the horns, he said to the cock: "When you want your horns back, you must call out at dawn: „Give me back my horns! "ee and they will be returned to you at once. You need have no occasion to be concerned in the least.

\section{Evaluation}

The kind cock knew how difficult it was to ascend to heaven, so, reassured by the good security the millipede offered, he loaned his horns without hesitation, just twisting them right off his head. He also thought to himself that when the dragon returned from his visit to heaven, they could sit down and have a good conversation; he would ask the dragon to tell

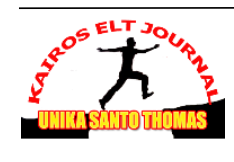


him how things were in heaven, and if it really was true, he might consider going there himself someday, he thought.

\section{Complication}

So, next morning at day break (for the dragon "s visit was scheduled to be brief), the cock called out loudly: "Give me back my horns!" but, even thought he repeated this demand ten times over, there was no sign at all of either the dragon or the horns. Worried, the cock promptly went off to complain to the millipede, who soothed him, saying: ," If the dragon has not returned the horns this morning, then he will certainly do so tomorrow. At the very latest, the day after that, just learn to be a little patient and your horns will soon be back on your head, just as before."

\section{Resolution}

Even so, the cock has not yet given up hope of getting his horns returned. He ordered his descendants always to call out at the break of day: "Give me back my horns!" He still hopes that the dragon may hear him!

(Text source: Doddy, et.al 2008:35)

\section{Significant Lexicogrammatical Features}

Gerot and Wignel (1994:204) state that narrative text has some lexicogrammatical features, they are:

a. Focus on specific and usually individualized participants

Example: from the text above the participants are cock, millipede

b. Use of material processes

Example: The millipede came for the horns.

Actor Material Goal

c. Use of relational processes and mental processes

\section{RESEARCH METHOD}

The research approach is quantitative. It has function to gathering information focuses on describing a phenomenon across a larger number of participants thereby providing the possibility of summarizing characteristics across groups or relationships. The research method is descriptive. The descriptive method describes and interprets what is. It is concerned with condition or relationships that exist. And the research design that is used is correlational design. Fraenkel and Wallen (1990:9) stated that correlational design is done to determine relationships among two or more variables. It attempts to investigate possibility relationships among variables without trying to influence those variables.

There are two variables in this study. The first is dependent variable that is students ${ }^{\text {ee }}$ vocabulary mastery and the second is independent variable that is students ${ }^{\text {ee }}$ ability in arranging narrative paragraphs. There is a connection between the two variables. As we know vocabulary is the basic in learning languages. Students will not be able to arrange narrative paragraphs if they don ${ }^{e e}$ know the meaning of the sentences. So, there is connection between vocabulary mastery and students ${ }^{\text {ee }}$ ability in arranging narrative paragraphs.

\section{DATA ANALYSIS}

\section{The Data}

The data of this study are the students ${ }^{\text {ee }}$ vocabulary scores and studentse ${ }^{\text {ee }}$ scores in arranging narrative paragraphs. The students ${ }^{\text {ee }}$ vocabulary scores are indicated by $(\mathrm{X})$, while the students ${ }^{\text {ee }}$ scores in arranging narrative paragraphs is indicated by (Y). From the data above it can be seen that the maximum score of vocabulary test is 87 and the minimum

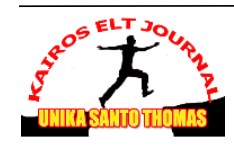


KAIROS ELT JOURNAL, Vol. 1, No. 3, December 2017

Copyright $\odot 2017$, ISSN: 2580-4278

score is 43. While in arranging narrative paragraphs test, the highest score is 90 and the lowest score is 27 (see appendix 1) The mean of vocabulary score is 67.1 while the interval is 7 and standard deviation is 11 (see appendix 1). In arranging narrative paragraphs, the mean is 62.6 while the interval is 10 and standard deviation is 17 (see appendix 2).

Testing the Item Difficulty and Discrimination of the Test

Before the real test was done, the writer had done try out first to the class of XI IIS ${ }^{1}$ After that the writer calculated the item difficulty and discrimination of the test.

The Item Difficulty of Vocabulary Test

To find out the criteria of item difficulty of vocabulary test, it can be seen as the table below:

Table 4.1. The categories of item difficulty

\begin{tabular}{|c|c|}
\hline Item difficulty & Difficulty Degree \\
\hline $0.00-0.30$ & Difficult item \\
\hline $0.31-0.70$ & Moderate item \\
\hline $0.71-100$ & Easy Item \\
\hline
\end{tabular}

Arikunto, (2003)

After obtaining the result (see appendix 3), it was found that the item difficulty of vocabulary test as in the table below:

Table 4.2. The difficulty degree of vocabulary test

\begin{tabular}{|c|c|c|}
\hline Item Number & Item Difficulty & Difficulty Degree \\
\hline 12,18 & $0.00-0.30$ & Difficult item \\
\hline $7,9,15,17,20,21,25,26,29$ & $0.31-0.70$ & Moderate item \\
\hline $\begin{array}{c}1,2,3,4,5,6,8,10,11,13,14,16 \\
19,22,23,24,27,28,30\end{array}$ & $0.71-100$ & Easy Item \\
\hline
\end{tabular}

Based on the table above, it can be seen that there are 2 items that are difficult, 9 items that are moderate and 19 items that are easy.

The Item Difficulty of Arranging Narrative Paragraphs Test

After the item difficulty of arranging narrative paragraphs had been calculated (see appendix 4), the result was found as in the table below:

Table 4.3. The difficulty degree of arranging narrative paragraphs test

\begin{tabular}{|c|c|c|}
\hline Item Number & Item Difficulty & Difficulty Degree \\
\hline 3 & $0.00-0.30$ & Difficult item \\
\hline 2 & $0.31-0.70$ & Moderate item \\
\hline 1,4 & $0.71-100$ & Easy Item \\
\hline
\end{tabular}

The table above shows that the difficulty degree of item 3 is difficult. Item 2 is moderate, and item 1 and 4 are easy. 
KAIROS ELT JOURNAL, Vol. 1, No. 3, December 2017

Copyright $\odot 2017$, ISSN: 2580-4278

\section{The Item Discrimination of Vocabulary Test}

In the previous chapter, it has been mention that the item discrimination is used to indicate how far the single test item can distinguish the upper group from the lower group of the class. The categories of item discrimination can be seen in the table below:

Table 4.4. The categories of item discrimination

\begin{tabular}{|c|c|}
\hline Item Discrimination & Interpretation \\
\hline $0.00-0.20$ & Poor \\
\hline $0.21-0.40$ & Moderate \\
\hline $0.41-0.70$ & Good \\
\hline $0.71-100$ & Excellent \\
\hline
\end{tabular}

Arikunto (2003)

After obtaining the result (see appendix 5), it was found that the item discrimination of vocabulary test is as in the table below:

Table 4.5. The classification of item discrimination of vocabulary test

\begin{tabular}{|c|c|}
\hline Item & Classification \\
\hline- & Poor \\
\hline $1,5,6,7,12,13,14,15,16,17,18,19$, & Moderate \\
$20,21,25,26,27,29,30$ & \\
\hline $2,3,4,8,9,10,11,22,23,24$ & Good \\
\hline 28 & Excellent \\
\hline
\end{tabular}

Based on the table above, it can be seen that there are nineteen items which are moderate, ten items are good and one item is excellent.

\section{The Item Discrimination of Arranging Narrative Paragraphs Test}

After the item discrimination of arranging narrative paragraphs was calculated (see appendix 6), it is found the result as in the table below:

Table 4.6. The classification of item discrimination of arranging narrative paragraphs test

\begin{tabular}{|c|c|}
\hline Item & Classification \\
\hline 4 & Poor \\
\hline $1,2,3$ & Excellent \\
\hline
\end{tabular}

The table of the classification of item discrimination of arranging narrative paragraphs above shows that item 4 is poor and item 1,2,3 are excellent.

\section{Testing the Reliability of the Test}

The correlation coefficient of the reliability of the test in this study was obtained by applying the split half method. In calculating the reliability using this formula, the first steps the writer divided the scores into equivalent half based on odd number and even number. For example 1,3,5,7 up to 29 belong to odd number $(\mathrm{X})$ and 2,4,6,8, up to 30 belong to event number (Y). And then a Pearson $r$ between scores on the two halves of the test was computed. At last it is adjusted the half-test reliability using the Spearman-Brown form 


\section{The Reliability of Vocabulary Test}

After the scores was calculating by Pearson Product Moment formula based on odd numbers and even numbers, it is found that $r$ is 0.51 . It did not yet show the real reliability of the competence of vocabulary test. Then to find out the real reliability of the test the Spearman Brown formula was applied. And it is found that the real reliability of the vocabulary test is 0.67 (see appendix 7).

Table 4.7. The categories of the reliability of the test

\begin{tabular}{|c|c|c|}
\hline No & $\begin{array}{c}\text { The Estimated Reliability of the } \\
\text { Entire Test }\end{array}$ & Categories \\
\hline 1 & $0.80-1.00$ & The reliability is very high \\
\hline 2 & $0.60-0.79$ & The reliability is high \\
\hline 3 & $0.40-0.59$ & The reliability is sufficient \\
\hline 4 & $0.20-0.39$ & The reliability is low \\
\hline 5 & $0.00-0.19$ & The reliability is very low \\
\hline
\end{tabular}

Arikunto (2002:245)

Based on the categories of reliability of test above, it can be seen that the reliability of vocabulary test is high.

\section{The Reliability of Arranging Narrative Paragraphs Test}

After the data of arranging narrative paragraphs was analyzed, it is found that $r$ is 0.25 . It is also did not shows the real reliability of arranging narrative paragraphs. Then the estimated reliability of the entire test ( $\mathrm{rxx}$ ) is calculated and it is found that $\mathrm{r}_{\mathrm{xx}}$ is 0.41 . So, based on the categories of reliability of the test above, it can be concluded that the reliability of arranging narrative paragraphs is sufficient (see appendix 8).

\section{Discussion}

In order to know what the correlation coefficient is, the score both of vocabulary and arranging narrative paragraphs have been calculated by applying Pearson Product Moment Formula.

After the data was calculated, it is found that the value of correlation coefficient (r) is 0.881. To make it clearer, the writer also used SPSS in analyzing the data. Look at as the following: 
Table 4.8. The correlation between students' vocabulary mastery and ability in arranging narrative paragraph using SPSS

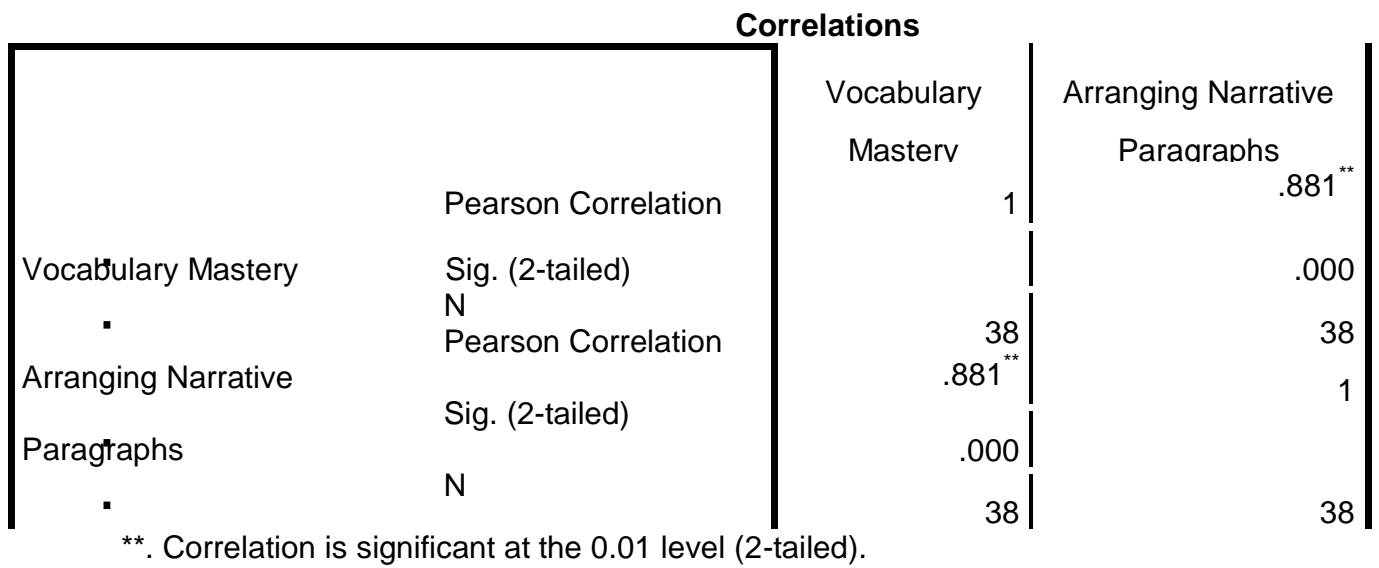

From the table above, it can be seen that correlation between vocabulary mastery and arranging narrative paragraphs is 0.881 . The value is same with the calculation by using Pearson Product Moment formula.

\section{Testing the Hypothesis}

In previous chapter, it has been mentioned that there are two the hypothesis in this research. The first is namely alternative hypothesis (Ha) is "there is a correlation between students $^{\text {ee }}$ vocabulary mastery and their ability in arranging narrative paragraphs at SMA Swasta St. Petrus Medan". The second is namely null hypothesis is "there is no correlation between students ${ }^{\text {ee }}$ vocabulary mastery and their ability in arranging narrative paragraphs at SMA Swasta St. Petrus Medan.

Having calculated the coefficient correlation between the two variables, the value of calculation $\mathrm{r}$ is 0.881 . While the value of $\mathrm{r}-$ table with the sample $\mathrm{N}=38$ at the level significance $0.05=0.320$ and at the level $0.01=0.413$. It shows that the value of r-observed is higher than the value of r-table $(0.881>0.413)$. Based on this finding, it implied that alternative hypothesis is accepted. And null hypothesis is rejected. So it can be concluded that there is a correlation between students ${ }^{\text {ee }}$ vocabulary mastery and their ability in arranging narrative paragraphs at SMA Swasta St Petrus Medan.

\section{Research Finding}

Having analyzed the data, the writer obtained that the coefficient correlation (r) is 0,881 .

Table 4.9. The categories of correlation coefficient

\begin{tabular}{|c|c|c|}
\hline No & r Coefficient & Correlation \\
\hline 1 & $0.80-1.00$ & Very strong \\
\hline 2 & $0.60-0.799$ & Strong \\
\hline 3 & $0.40-0.599$ & Moderate \\
\hline 4 & $0.20-0.399$ & Weak \\
\hline 5 & $0.00-0.199$ & Very weak \\
\hline
\end{tabular}

(Arikunto, 2002) 
Based on categories of correlation coefficient above it can be concluded that the correlation between the students ${ }^{\text {ee }}$ vocabulary mastery and ability in arranging narrative paragraph at second grade students of SMA Swasta St. Petrus Medan is very strong.

\section{CONCLUSIONS}

Based on the result of the data analysis, the conclusions are drawn as the following:

1. There is a correlation between the students ${ }^{\text {ee }}$ vocabulary mastery and their ability in arranging narrative paragraphs at SMA Swasta St. Petrus Medan in Academic Year of 2016/2017. The correlation is 0.881. Based on the category of correlation coefficient, it can be stated that the correlation between the two variables is very strong.

2. Students who are good at the vocabulary mastery are also good in arranging narrative paragraphs. It means that the more students master vocabulary, the easier for them in arranging narrative paragraphs.

\section{BIBLIOGRAPHY}

Anisa, Ike. 2010. Improving Students' Vocabulary Mastery Using Experimental Learning. An Unpublished Thesis. Klaten: Universitas Widya Dharma Klaten.

Anova, Candra, et.al. 2014. The Correlation between Students' Vocabulary Mastery and Speaking Skill at Fifth Semester of English Study Program in Pasir Pengairan University. An Unpublished Thesis. Riau: University of Pasir Pengairan.

Arikunto, Suharsimi. 2002. Prosedur Penelitian: Suatu Pendekatan Praktek. Edisi

Revisi V. Jakarta: Rineka Cipta.

Arikunto, Suharsimi. 2003. Prosedur Penelitian Suatu Pendekatan Praktik. Jakarta: Rineka Cipta.

Ary, Donald, et.al. 1979. Introduction to Research in Education (2 ${ }^{\text {th }}$ Ed). New York: Holt, Rinehart and Winston, inc.

Bram, Barli. 1995. Write Well. Yogyakarta: Kanisius.

Burn, Paul C and Betty L. Broman. 1975. The Language Arts in Childhood Education A Rationale for Pedagogy. Cambridge: Cambridge University Press.

Doddy, Achmad, et.al. 2008. Developing English Competencies for Senior High School (SMA/MA). Jakarta: Pusat Departemen Pendidikan Nasional.

Fauzi, Rizal Asep. 2012. Correlation Between Students' Vocabulary Mastery and Their Writing Narrative Ability at the First Grade Students of SMA Tut Wuri Handayani Cimah. An Unpublished Thesis. Bandung: Sekolah Tinggi Keguruan dan Ilmu Pendidikan (STKIP) Siliwangi..

Fraenkel, Jack R., Norman E, Wallen. 1990. How to Design and Evaluate Research in Education. New York: McGraw-Hill,inc.

Furqon, Fajar. 2013. Correlation between Students ${ }^{\text {ee }}$ Vocabulary Mastery and Their Reading Comprehension. Journal of English and Education, 1(1),68.80. 
KAIROS ELT JOURNAL, Vol. 1, No. 3, December 2017

Copyright $\odot 2017$, ISSN: 2580-4278

Gerot, Linda., Peter, Wignell. 1994. Making Sense of Functional Grammar. Sydney: Gerd Stabler.

Hatch, E. \& C, Brown. 1995. Word Classification: En Vocabulary, Semantics and Language (pp.218-260). Reino Unido: Cambridge University Press.

Herzog, David A. 2005. Webster's New World; Essential vocabulary. Canada: Wiley, Hoboken, NJ.

Joyce, H., \& Feez, S. 2000.Writing Skills: Narrative and Non-fiction Text Types. Sydney: Phoenix Education Pty Ltd.

Kasim, Nur Aeni. 2010. Increasing the Students' Vocabulary Mastery by Using Word Wall Media. An Unpublished Thesis. Makasar: Universitas Negeri Makasar (UNM).

Kon, T.S. 1991. Primary 4 Vocabulary Practice with Wordlists. Indonesia: Binarupa Aksara.

Mulyaningsih, Dini Utami. 2013. An Analysis of Students ${ }^{\text {ee }}$ Ability in Writing Narrative Texts. Journal of English and Education, 1(12),16-22.

Nation, P. \& Newton, J. 1997. Teaching Vocabulary. Cambridge: Cambridge University Press.

Neuman, S.B and Dwyer, J. 2009. Missing in Action: Vocabulary Instruction in Pre-k. The Reading Teacher. 62(5),384-392.

Nuh, Mohammad. 2014. Bahasa Inggris. Jakarta: Pusat Kementrian dan Perbukuan Kemdikbud.

Reid, Joy M. 1987. The Process of Composition. London: Prentice-Hall International

Setiawan, Budi. 2008. Improving the Students' Vocabulary Mastery through Direct Instruction. An Unpublished Thesis. Surakarta: Sebelas Maret University.

Toolan, M. J. 2001. Narrative: A Critical Linguistic Introduction. London: Routledge. 